\title{
Perancangan Permainan Ular Tangga Multiplayer Berbasis Android
}

\author{
Rahmat Hidayatullah ${ }^{1}$, Atma Hadiansa ${ }^{2}$ \\ ${ }^{1}$ STMIK Dumai, Riau \\ ${ }^{2}$ AMIK Dumai, Riau \\ 1,2 Jalan Utama Karya Bukit Batrem Dumai-Riau
}

Abstrak

Permainan ular tangga merupakan permainan yang banyak digemari pada telepon seluler beberapa tahun yang lalu, namun seiring berkembang nya teknologi masyarakat sekarang banyak menggunakan telepon selular berbasis android, sehingga game snake yang sempat digemari juga tertinggal. Seiring berkembangnya game sesuai dengan teknologi, game konvensional yang dulunya banyak diminati menjadi tertinggal. Oleh karena itu di dalam penelitian ini permainan ular tangga akan merancang sebuah permainan ular tangga dengan metode waterfall dan algoritma backtracking tujuan dari penelitian ini adalah permainan ini dapat berjalan pada OS Android Jellybeans hingga versi OS Android terbaru.

Kata Kunci : Ular Tangga, Metode Waterfall, Backtracking, Android

\section{Abstract}

Snake game ladder is a much-loved game on the cellular telephone a few years ago, but as it grew its technology today many people use cell telephone based on android, so snake game that had rucked also lagged. As the game develops in accordance with technology, conventional games that used to be a lot of interest to be left behind. Therefore in this research the ladder snake game will design a game of snake ladder with waterfall method and backtracking algorithm purpose of this research is this game can run on Jellybeans Android OS until latest Android OS version.

Keywords: Snake Ladder, Waterfall Method, Backtracking, Android

\section{PENDAHULUAN}

Ular tangga merupakan permainan yang dimainkan dengan media papan permainan dan dilengkapi oleh seperangkat dadu yang dapat dimainkan oleh 2 (dua) pemain atau lebih. Papan permainan terdapat kotak-kotak kecil berjumlah 100 kotak (ukuran 10 x 10) dan pada beberapa kotak permainan terdapat beberapa gambar "tangga" atau "ular" yang terhubung dengan kotak lain. Untuk menyelesaikan atau memenangkan permainan, para pemain harus berusaha menjadi orang pertama yang berhasil mencapai kotak nomor 100 (finish).

Game merupakan salah satu hiburan yang dapat memberikan kepuasan batin bagi pemainnya. Bentuk game atau permainan dapat dimainkan melalui beberapa media, salah satunya melalui media elektronik. Kehadiran Android sebagai sebuah sistem operasi yang bersifat Open Source memberikan dampak perubahan yang besar bagi para penggiat game, khususnya dalam menghasilkan karya-karya game mereka yang dapat digunakan pada beragam perangkat, termasuk perangkat Android yang saat ini sedang berkembang dengan pesat.

Pada saat awal munculnya permainan ular tangga, permainan ini menggunakan kertas yang mana didalamnya terdapat 100 kotak yang bergambar tangga dan ular, dimainkan oleh 2 orang atau lebih dengan menggunakan dadu sebagai cara menjalankan bidak para pemain. Namun, dengan adanya aplikasi berbasis Android ini mampu memberikan peluang permainan ular tangga menjadi permainan yang interaktif dan dirancang dengan tampilan visual lebih menarik dan menggunakan beberapa aturan-aturan ular tangga yang dapat dimainkan secara bersama melalui perangkat Android. Representasi prosedural akan digunakan sebagai teknik dalam menggambarkan aturan atau kaidah pengetahuan yang ada dalam permainan ular tangga. Representasi Prosedural adalah salah satu teknik dalam pemrograman Artificial Intelligence atau Kecerdasan Buatan, yaitu ilmu komputer yang mempunyai kemampuan berorientasi otak manusia itu sendiri.

\section{TEORITIS}

\subsection{Permainan}

Permainan merupakan suatu bentuk aktivitas menyenangkan yang dilakukan oleh manusia, untuk mendapatkan kesenangan dari permainan itu, bukan untuk menghasilkan sesuatu.

Sebagaimana yang dijelaskan Egi M Wiranata (2016) dalam jurnalnya, ia mengatakan dalam sebuah permainan diperlukan alat dan aturan bermain. Sehingga untuk memperoleh kemenangan, para pemain membutuhkan keterampilan diri, taktik, kesempatan dan bahkan membutuhkan keberuntungan. Permainan dapat dilakukan dengan 2 cara, yakni pemain tuggal (Single Player) ataupun banyak pemain (Multi Players). Pada permainan tunggal, membutuhkan keterampilan diri sendiri untuk melewati tantangan-tantangan yang diberikan, 
sedangkan pada permainan dengan banyak pemain, selain menggunakan kemampuan diri juga memerlukan kesempatan dan strategi untuk memenangkan permainan[1].

\subsection{Kecerdasan Buatan}

Menurut Sri Kusumadewi (2003) Kecerdasan buatan merupakan "pengetahuan yang berguna menjadikan sebuah mesin (komputer) mampu beroperasi terhadap sebuah instruksi dan menyelesaikan perintahnya sebaik yang dilakukan oleh manusia[2]. Definisi di atas menunjukkan bahwa kecerdasan buatan (AI) adalah sebuah kemampuan yang dapat ditanamkan pada komputer berdasarkan sound theoretical (teori suara) dan prinsip prinsip aplikasi dari bidangnya. Prinsip - prinsip ini meliputi struktur data, algoritma, bahasa dan teknik pemrograman yang digunakan dalam merepresentasikan pengetahuan manusia ke dalam sebuah komputer.

\subsection{Metode Waterfall}

Menurut Pressman (2015), Model Waterfall merupakan sebuah pendekatan sistematis dan runut, biasanya model ini digunakan dalam pengembangan rekayasa perangkat lunak. Tahapan yang terdapat pada model waterfall terdiri dari beberapa tahapan, yakni Planning, Modelling, Construction, serta Deployment dan diakhiri dengan dukungan secara berkelanjutan pada perangkat lunak yang dihasilkan[4].

\subsection{Algoritma Backtracking}

Sebagaimana yang dikemukakan oleh Rinaldi Munir (2004), algoritma backtracking pada prinsipnya sama dengan brute-force, yaitu mencari segala kemungkinan solusi yang dapat digunakan untuk memecahkan masalah. Oleh karena itu, algoritma ini menggunakan Depth-First Search (DFS), dalam mencari solusi pada suatu struktur berbentuk pohon berakar. Pada proses pencarian solusi ini, DFS mencari dari simpul terdalam terlebih dahulu, hingga menghasilkan sebuah solusi yang layak untuk digunakan[5].

\section{ANALISA DAN PEMBAHASAN}

\subsection{Rancangan Arsitektur Game}

\section{Use Case Diagram}

Use Case Diagram merepresentasikan secara umum proses dan sistem permainan tersebut berjalan, mendeteksi lingkungan (environtment) dan aktor yang yang terlibat dalam sebuah proses dan sistem permainan tersebut. Use case secara tidak langsung memberikan pengetahuan mendasar bagaimana sistem bekerja dan memudahkan dalam pengorganisasian sistem dan prosesnya. Berikut ini merupakan gambaran sistem dari sisi pengguna.

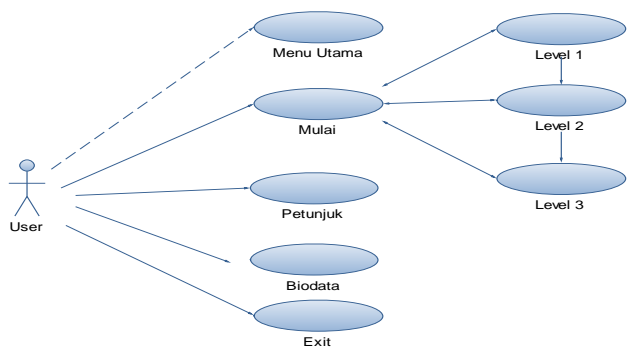

Gambar 1. Use Case Diagram

\section{Analisis Class Diagram}

Kelas-kelas yang diperlukan dalam pembuatan perangkat lunak klasifikasi berita ini adalah sebagai berikut:

1) Kelas Utama (Main Menu)

Kelas ini berfungsi sebagai kelas utama karena terdapat komponen berupa menu pilihan yang dapat digunakan untuk menjalankan permainan, seperti tombol mulai, tombol petunjuk, tombol biodata, dan tombol exit.

2) Kelas Proses

Kelas ini digunakan untuk mengambil dan memproses data di sistemnya.

3) Kelas Koneksi

Kelas ini dikelompokkan sesuai dengan kegunaan dalam pemograman, misalnya untuk kelas utama di sini pemain dapat memilih tombol mulai untuk memulai permainan, tombol petunjuk sebagai petunjuk permainan, tombol biodata sebagai informasi catatan pembuat atau pengembang game ular tangga dan tombol exit untuk keluar dari permainan. Semua kelas itu saling berhubungan dan tidak dapat berdiri sendiri, sebab semua kelas 
di pakai dalam perancangan. Misalnya untuk memutar dadu maka dibutuhkan class objek dan class nomor random.

\section{Activity Diagram}

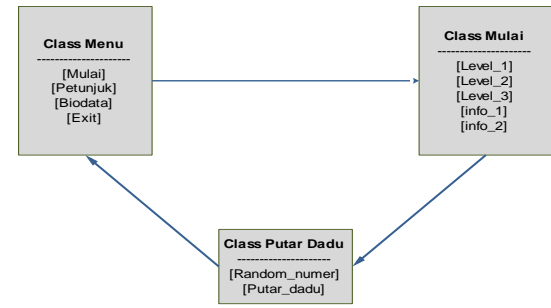

Gambar 2. Class Diagram

Activity diagram digunakan untuk memodelkan aspek dinamis dari sistem. Dari sisi fungsinya, Activity diagram mirip dengan diagram alir (flowchart), yang berguna untuk memperlihatkan aliran kendali dari suatu aktifitas ke aktivitas yang lain.

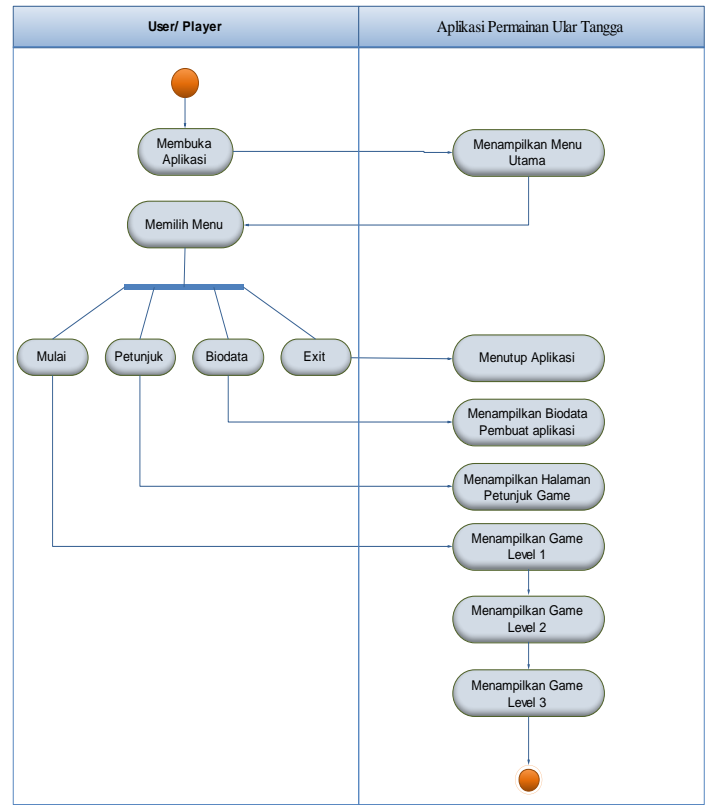

Gambar 3. Gambar Activity Diagram

\section{Sequence Diagram}

Pada Sequence diagram berikut ini bisa dilihat bahwa yang menjadi Actors adalah pemain. Activation boxes memiliki garis indikator yang berfungsi untuk menginformasikan terjadinya aktifitas antara Actors dan Object.

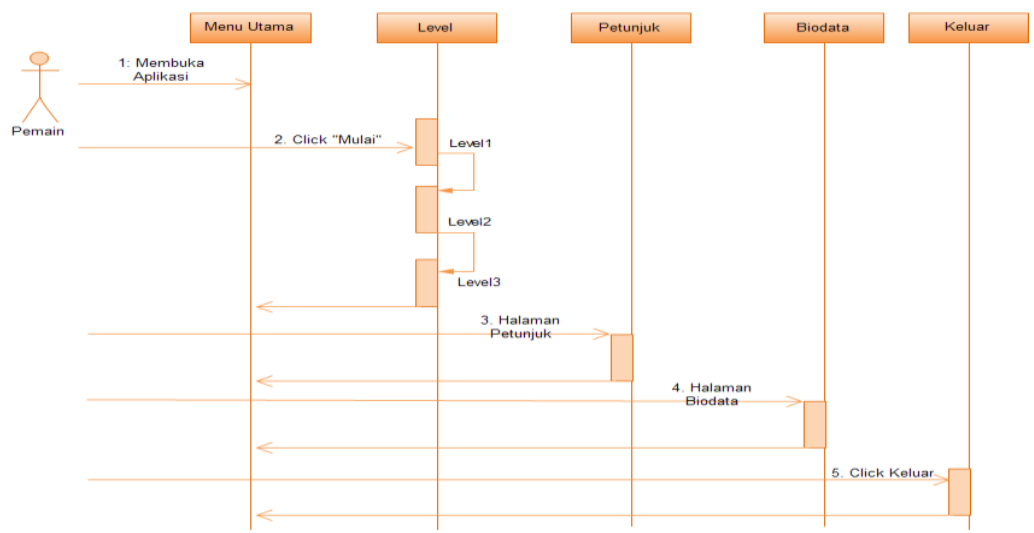

Gambar 4. Sequence Diagram

Rahmat Hidayatullah | http://ejurnal.stmik-budidarma.ac.id/index.php/mib | Page | 93 


\section{Flowchart Permainan Ular Tangga}

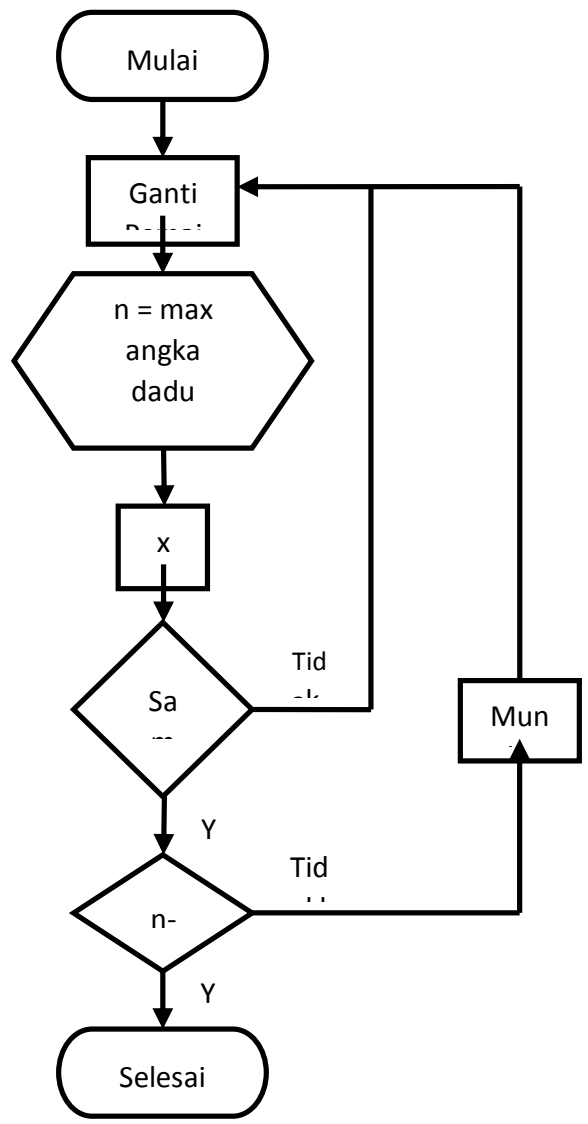

Gambar 5. Flowchart Permainan Ular Tangga

5. Flowchart tangga "naik" dan ular "turun"

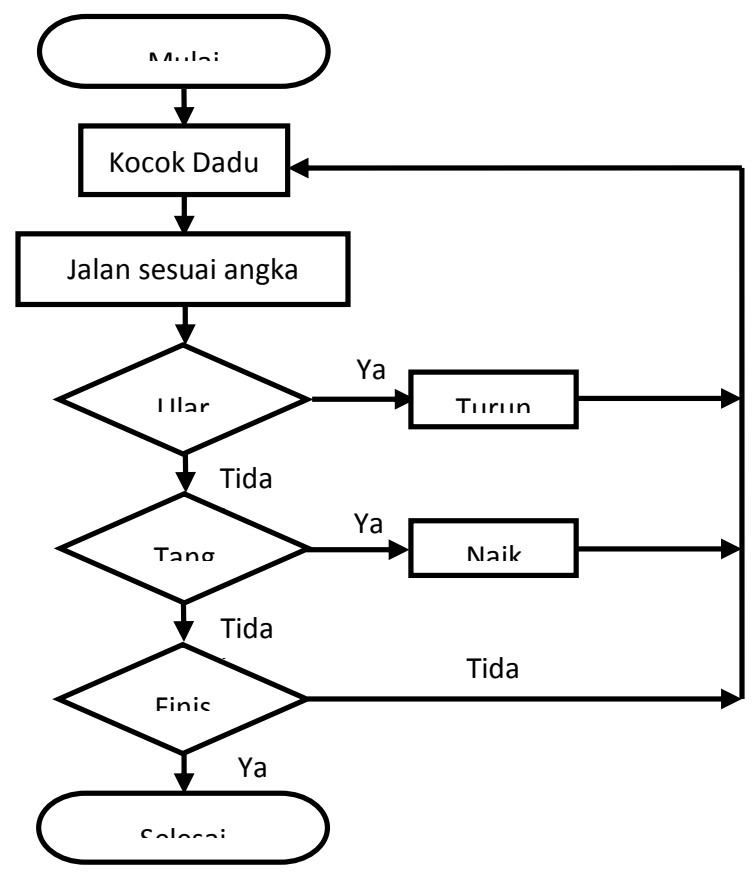

Gambar 6. Flowchart tangga "naik" dan ular "turun"

Rahmat Hidayatullah | http://ejurnal.stmik-budidarma.ac.id/index.php/mib | Page | 94 


\section{Tampilan Menu Utama}

Pada halaman menu utama terdapat pilihan mulai, petunjuk, biodata dan exit. Jika ingin memulai permainan pemain dapat memilih dengan klik tombol Mulai untuk masuk ke dalam permainan dan menampilkan layout level 1 (gambar. 7), tombol petunjuk berisi tentang cara-cara dan aturan dalam bermain ular tangga, tombol biodata berfungsi untuk melihat biodata tentang pengembang permainan ini, sedangkan tombol exit berfungsi apabila pemain ingin keluar dari permainan ini.

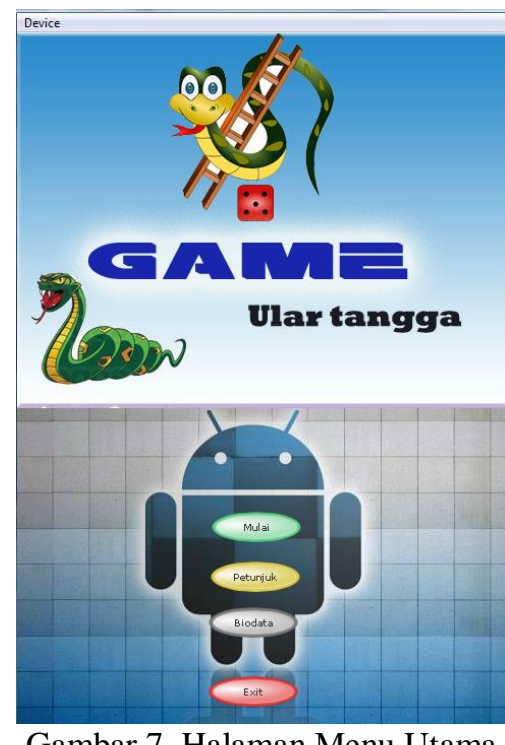

\section{Tampilan halaman petunjuk permainan}

Pada halaman petunjuk, berisi tentang aturan dan cara-cara memainkan game ular tangga antara lain :

1. Giliran lempar dadu pertama kali kepada pemain 1

2. Apabila pemain memperoleh dadu angka 6 , maka pemain tersebut berhak untuk melempar dadu selanjutnya

3. Bila bidak pemain berhenti pada kotak yang memiliki anak tangga, pemain berhak menjalankan bidaknya sesuai dengan kotak yang dituju oleh anak tangga.

4. Begitupun bila pemain berhenti pada kotak yang terdapat gambar ular, harus menurunkan bidaknya sesuai dengan panjangnya gambar ular dan berhenti pada suatu kotak tertentu.

Terdapat tombol kembali yang berfungsi untuk masuk ke halaman sebelumnya yaitu halaman menu utama:

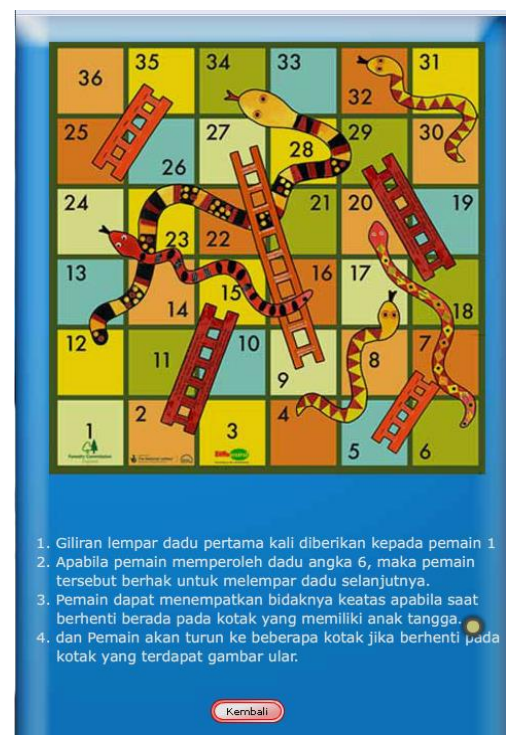

Gambar 8. Halaman Petunjuk 


\section{Tampilan game play level 1}

Setiap level tertentu, pemain akan menggunakan desain layout ular tangga yang berbeda-beda, dimana masingmasing desain layout memiliki tingkat peluang finish yang semakin kecil antara level 1 hingga level 3. Untuk memulai permainan, pemain pertama dan kedua harus menekan tombol putar dadu untuk mendapatkan nilai dadu secara random / acak, kemudian pemain menekan tombol jalankan untuk menjalankan bidaknya sesuai nilai dadu secara bergantian dan seterusnya hingga salah satu pemain mencapai kotak terakhir atau finish. Berikut ini desain layout game play level 1.

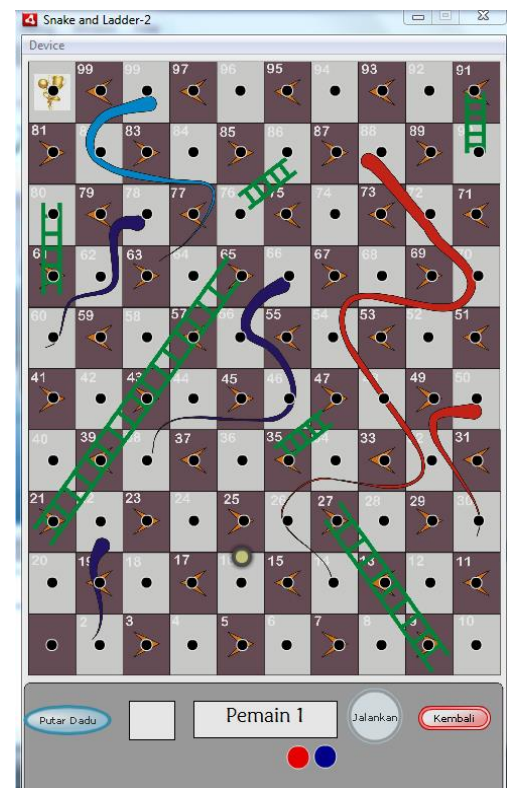

Gambar 9. Halaman Game play level 1

\section{Tampilan game play level 2}

Bisa dilihat pada desain layout game play level 2 pada kotak 91 hingga 100 terdapat 3 kotak yang terdapat kepala ular, sehingga peluang untuk mencapai kotak 100 akan menjadi lebih sulit. Berikut tampilan layout pada level 2.

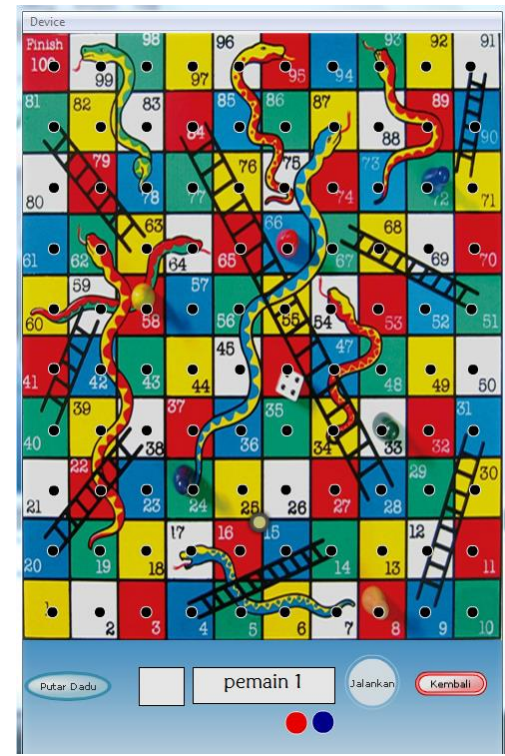

Gambar 10. Halaman Game play level 2

\section{Tampilan game play level 3}

Sementara pada desain layout game level 3. Jumlah ular lebih banyak yaitu sebanyak 10 ekor, dibandingkan dengan game level 2 yang hanya berjumlah 8 ekor. Sehingga pada level 3 ini pemain akan memiliki peluang untuk 
dimakan ular lebih banyak dari pada level sebelumnya, dan tentunya permainan akan menjadi semakin seru. Berikut tampilan layout game play pada level 3.

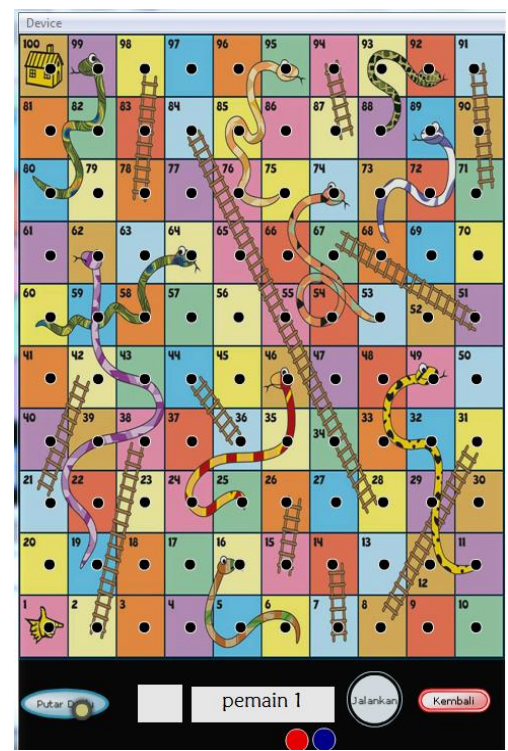

Gambar 11. Halaman Game play level 3

Desain halaman jika pemain 1 atau 2 menang.

Saat memainkan game ini persaingan untuk memperoleh finish pertama antara pemain 1 dan 2 akan semakin seru. Untuk itu sebagai informasi apakah pemain 1 atau pemain 2 yang memperoleh kemenangan, maka akan ditampilkan halaman informasi pemenang untuk tiap level yang dijalani. Untuk itu aplikasi akan menampilkan halaman pesan sebagai berikut :

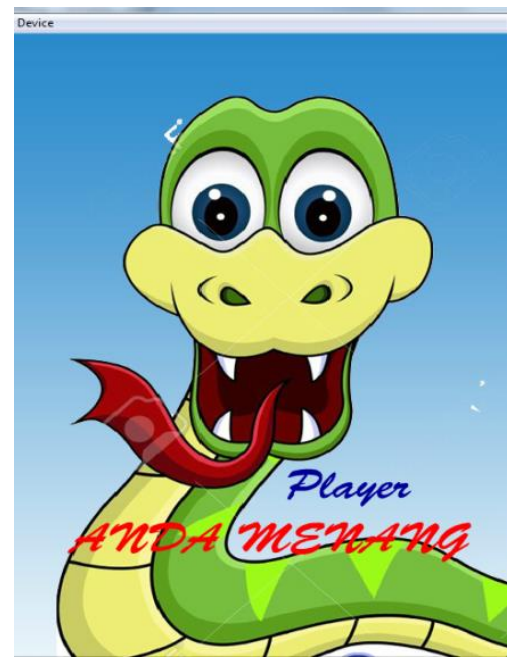

Gambar 12. Halaman Informasi Pemain Menang

\section{KESIMPULAN}

Dari hasil penelitian penulis menarik beberapa kesimpulan, yaitu:

1. Permainan ular tangga berbasis Android ini dapat diimplementasikan pada perangkat Smartphone dengan baik dan dapat dinikmati dengan tampilan visual yang menarik.

2. Permainan ular tangga di rancang dengan penambahan audio agar lebih menarik dan memberikan kesegaran bagi penggemar game.

3. Selain untuk menghibur diri, game ini mampu melatih kesabaran dan memberikan tantangan pada pemain untuk mencapai finish dalam setiap level yang berbeda. 
4. Permainan ini dapat berjalan dengan lancar pada perangkat smartphone dengan minimal versi android Jelly Beans.

\section{REFERENCES}

[1] Egi M Wiranata dkk (2016) Rancang Bangun Permainan Android Tiga Dimensi Teka Teki Rumah Bubungan Lima Dengan Metode Kecerdasan Buatan, Jurnal Rekursif, Vol. 4 No.1Maret 2016, ISSN 2303-0755.

[2] Sri Kusumadewi, (2003). “Artificial Intelligence (Teknik dan Aplikasinya )"Graha Ilmu

[3] Anis Ramadhani. (2013). Jurus Rahasia Pintar Menguasai Android Untuk Pemula. Kir Direction. Jakarta.

[5] Pressman, R. 2015. Rekayasa Perangkat Lunak: Pendekatan Praktisi Buku 1. Yogyakarta: ANDI.

[6] Rinaldi Munir. (2004). Algoritma Runut-balik (Backtracking). Departemen Teknik Informatika Institut Teknologi Bandung. Bandung.

[7] J. Simarmata, Rekayasan Perangkat Lunak. Bandung: Andi Offset, 2015.

[8] M. Mesran, "PEMANFAATAN MOBILE DEVICE PADA UJIAN MATAKULIAH MENERAPKAN LINEAR CONGRUENT METHOD (LCM) BERBASIS ANDROID," Teknol. dan Sist. Inf., vol. 2, no. 2, pp. 80-85, 2016.

[9] C. Crawford, Chris Crawford on Game Design. USA: Peachpit, 2003.

[10] A. Nilwan, Pemrograman Animasi dan Game Profesional 4. Jakarta: Elex Media, 1998.

[11] A. Ismail, Education Games, Menjadi Cerdas dan Ceria dengan Permainan Edukatif. Yogyakarta: Pilar Media, 2006. 